\title{
Julkisen sektorin nurkanvaltaajat
}

Hanna Kuusela \& Matti Ylönen (2013):

Konsulttidemokratia - miten valtiosta tehdään tyhmä ja tehoton.

Gaudeamus, Helsinki. 200 s.

ISBN 978-952-495-290-3.

AikuisKasvatukselle mikä tahansa demokratian ajankohtaista tilaa käsittelevä tutkimus on relevantti. Monista erityisistä syistä tämä pätee myös Kuuselan ja Ylösen kirjaan.

Yleensä pamfletit ovat helppoa ja kiinnostavaa luettavaa kirjoittajan tai kirjoittajien kiistojen ja väittämien vuoksi. Konsulttidemokratia-kirja ei ole kuitenkaan pamfletti, vaan haastatteluaineistoihin, tilastoihin ja kirjallisiin dokumentteihin perustuva tutkimus, niin sanottu puheenvuorokirja, joka pitää lukijan hyvin otteessaan. Kuvaan tässä arvioinnissa lyhyesti kirjan sisältöä, mutta jätän itse herkullisen aineiston lukijan tavoitettavaksi. Lisäksi nostan esille muutaman erityisen syyn, miksi tämä kirja on aikuiskasvatukselle tärkeä.

\section{PELKURIVALTIO ON TYHMÄ JA TEHOTON}

Johdannossa kirjoittajat kuvaavat konsulttidemokratian käsitettä ja ilmiötä sekä kirjan perustehtävää. Myös kirjoittajien omat motiivit ja orientaatio tulevat esille johdantoluvussa, ja niistä olisi opiksi yleisemminkin tutkijoille. Kuinka säilyttää perustutkimuksen ja -työn kentällä herkkyys tarttua ajankohtaiseen ja tärkeään teemaan? Tai kuinka tuo perustutkimus tai oma työ voi tarjotakin ad hoc-tilaisuuksia uusien tärkeiden ilmiöiden tutkimiseen? Molemmat kirjoittajat ovat tietokirjailijoita. Kuusela on Suomen Akatemian tutkija ja Ylönen toimittaja. Molemmat ovat myös itse tehneet konsultointia.

Kirja jakautuu johdannon lisäksi kolmeen lukuun ja epilogiin.
Kuusi erityisteemaa on kehystetty erikseen tietolaatikoiksi. Ensimmäinen luku valottaa hallinnon kehityksen suuria linjoja, joihin 1980-luvulta lähtien on haettu "vallankumouksellisia" muutoksia, ketteryyttä ja säästöjä. Poliittiset linjaukset valtion ja julkisten palvelujen tehostamiseksi ovat luoneet otollisen pohjan konsultointityön vahvalle nousulle.

Lähinnä uusliberalistisessa talousajattelussa hyvinvointivaltio on mielletty tehottomaksi julkiseksi palveluksi ja yksityinen yritystoiminta tehokkaaksi, ketteräksi ja taloudelliseksi. Konsultoinnin ideaalit ovatkin peräisin viimeksi mainitusta, ja hyvinvointivaltio on monella tavalla korvautumassa valmentajavaltiolla, jonka tärkeimmät toimintaideat on omaksuttu juuri yrityselämäs- 
tä. Perinteinen edustuksellisuus ja demokratia korvautuvat näin ketterillä ostopalvelukonsulteilla.

Toinen luku on laajin ja antaa tilaa asiaa koskeville, haastatteluihin perustuville kertomuksille ja dokumentaatiolle. Konsulttidemokratian seurauksia ovat kirjoittajien mukaan riippuvuussuhteet, hiljaisen tiedon vaarantuminen, ostetun tiedon epäluotettavuus ja muut sellaiset tekijät, joilla valtiosta on todellakin suunnitelmallisesti tehty sekä tyhmää että muutettu se tehottomaksi hoitamaan julkisia palvelujaan. Viimeisessä luvussa kirjoittajat etsivät ja esittävät teesejään päästä "pelkurivaltiosta" takaisin vahvaan ja toiminnalliseen valtioon.

\section{KONSULTOINNIN \\ KUSTANNUKSET}

\section{ENNAKOIMATTOMIA}

Kirjassa konsultointia kuvataan yksityiseltä sektorilta julkiselle siirtyneeksi ja laajentuneeksi toiminnaksi, jolle erityisesti lamat ja niiden myötä säästötoimet ovat antaneet puhtia.

Kun lamakausi vähentää konsultointia yksityissektorilla, se on saanut lisääntyvästi jalansijaa julkisella puolella. Tämä väliaikaiseksi tarkoitettu ulkoinen apu on salakavalasti muuttunutkin enemmän tai vähemmän pysyväksi ja vienyt julkista valtaa yksityiselle sektorille sekä romuttanut demokraattisia toimintatapoja.

Monin esimerkein kirjoittajat tuovat esille, kuinka konsultointitoimeksiannot antavat asiansa tuntevalle konsultointipalvelun myyjälle tilaisuuksia niin sanottuun nurkanvaltaukseen ja oman konsulttiyrityksen kiinnittämiseen palvelun tilaajaan. Useimmissa tapauksissa tilaaja (valtio tai kunnat) eivät omista itselleen tehtyä palvelua, vaan se jää konsultointiyrityksen omaisuudeksi. Esimerkkinä voidaan mainita tietotekniikkapalveluyritys Tieto, joka omistaa Valviran Terhikkijärjestelmän eli terveydenhuollon ammattilaisten keskusrekisterin.

Samalla konsultointi on osoittautunut omassa asiassaan (tehokkuudessa, ketteryydessä ja säästäväisyydessä) lähinnä retorisiksi lupauksiksi ja kääntänyt toiminnan kustannukset perinteisiä palveluja suuremmiksi.

\section{OSAAMINEN KATOAA ORGANISAATIOISTA}

Mitä tekemistä edellisellä on demokratian lisäksi aikuiskasvatuksen kanssa? Vielä muutama vuosi sitten puhuttiin 1990-luvun alussa alkaneesta "oppivan organisaation” käsitteestä, mutta nyt sen tarina on hiljentynyt. Jos siitä puhutaan, niin se tapahtuu byrokraattisen organisaation kritiikkinä ja useimmiten organisaatioon tarvittavan ulkoisen, konsultoivan tai valmentavan intervention tarpeena.

Tähän asiaan liittyy kirjoittajien esiin nostama huoli osaamisen ulkoistumisesta ja hiljaisen tiedon hiipumisesta; useissa tapauksissa konsultit alkavatkin tietää ja osata organisaation toiminnat paremmin kuin varsinaiset työntekijät. "Ulkoistaminen johtaa siihen, että organisaatiossa ei ole enää yhtään henkilöä, joka löytäisi pannuhuoneen talossa”, on erään haastateltavan pelkojen päätepiste.

Erityisesti kirjassa tuodaan esille huoli siitä, kuinka IT-uudistuksissa julkisen palvelun tuottajia (eli konsultointipalvelujen ostajia) on viety kuin pässiä narussa ja sekä tieto, osaaminen että itse järjestelmät ovat siirtyneet ulkoisten palveluntuottajien omaisuudeksi.

Tätä huolta eivät esitä kirjoittajat omina tulkintoinaan, vaan kirjan aineisto tuo esille, että Valtiontalouden tarkastusvirasto (VTV) on raporteissaan toistuvasti joutu- 


\section{\%}

nut kysymään näiden perään. Erityisen huomionarvoista VTV:n havainnoissa on se, että myös niissä painotetaan osaamisen katoamisesta aiheutuvaa kestoprobleemaa. Osaaminen on näin olennaista organisaation taloudellista pääomaa, jota on tarkasteltava kvartaalitulosten ja lisääntyvien pinnallisten tulosmittausten sijaan pitkällä perspektiivillä ja osaamista kehittävillä kriteereillä.

\section{ONKO JO LIIAN MYÖHÄISTÄ?}

Kirja osuu työssä oppimisen ja kehittymisen edellytysten ytimeen. Oleelliset oppimista ja kehittymistä ylläpitävät tekijät löytyvät organisaatioissa tyypillisesti yllättävän läheltä, toisilta toimijoilta ja vertaisilta. Ongelmaksi oppimisen ja kehittymisen kannalta nouseekin se, että organisaatioissa alkaa olla tärkeiden asioiden kohdalla aukkoja. Näissä vertaista ei ole, kokemuksista ei päästä puhumaan tai muutoin "hiljaisen tiedon kerrottavuuden edellytykset heikkenevät”, kuten kirjoittajat sosiologi Richard Sennettiin viitaten kuvaavat (s.92).

Jatkokertomus julkisen sektorin tehottomuudesta ei ole kirjan esimerkkien ja argumentaation perusteella tarpeen - valtio ja kun- nat selviävät vähintään yhtä hyvin funktioistaan kuin "innovaatioilla" itsensä myyvät ulkoiset auttajat ja palveluntarjoajat.

Erityisesti, jos otetaan huomioon osaamisen kehittäminen, ulkoinen konsultointi näyttäisi vakiintuessaan syövän oleellisen resurssin henkilöstön kvalifikaatioiden ylläpitämisestä. Kysymys on edellytysten tukemisesta ja oman toiminnan arvon ylläpitämisestä, mitä poliittiset päätöksentekijät ja julkishallinnon ylin johto eivät ole itse kyenneet rakentamaan.

Kirjoittajat eivät näekään ensi sijaisen kritiikin kohteeksi itse konsultteja, jotka ovat osanneet toki käyttää tilannetta hyväkseen. Monen asian kohdalla voidaan kysyä, onko jo liian myöhäistä palauttaa takaisin luottamus julkisten palvelujen osaamiseen ja sen kykyihin kehittää itseään?

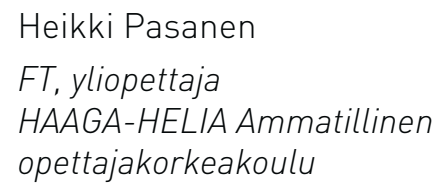

